\title{
10
}

\section{Exiles and Empty Houses: Contingent Events and Their Aftermath in the Ok Tedi Hinterland}

\author{
Dan Jorgensen
}

\section{Introduction}

Not long ago I had a conversation with Martha Macintyre in which she explained how she got into anthropology. A historian by training, she was recruited as bibliographer to the Cambridge Kula Conference (Leach \& Leach, 1983; Macintyre, 1983a, 1983b; see also Gregory, this volume). One of the things that struck her then was that it seemed time for a historical approach to some of the classic themes of Melanesian ethnography (see e.g. Macintyre, 1994). ${ }^{1}$ Macintyre's historian's sensibility is also evident in her work with Rolf Gerritsen on mining on Misima, which is located in the chain of island communities engaged in kula exchanges (Gerritsen \& Macintyre, 1991). For me, what stands out in that account is how the temporal unfolding of the project resulted in a reversal of Misiman positions on whether the workforce should reside on Misima

1 In fact, Macintyre's initial fieldwork on Tubetube formed part of the broader kula project, in which she filled gaps and brought aspects of the historical southern Massim record up to date (1983b, p. 379). 
or operate on a fly-in fly-out (FIFO) basis. Published five years after their initial social impact study, their chapter stands as a detailed postscript that reflects events and their aftermath in real time.

Historians cannot remain indifferent to events and the passage of time; as Macintyre took pains to argue, neither can ethnographers. This is clear in the course of initial fieldwork (Jorgensen, 1980, 1981a), where expectations are continually revised in light of events in the field. But things keep on happening after the ethnographer leaves, as anyone who has made follow-up visits realises. In my own case, much of my subsequent fieldwork in Telefomin in the highlands of Papua New Guinea (PNG) has been inadvertently historical and twice occurred in response to explicit Telefol requests. In each case, the request was triggered by what local people understood to be significant and potentially game-changing events - the first being the emergence of revival evangelism less than four years after my fieldwork on Telefol religion (Jorgensen, 1981b). This was later followed by work on the prospects of large-scale mining (Jorgensen, 1983, 1990a, 1990b, 1997).

In what follows, I take up problems posed by focusing on events as contingent interruptions of the usual flow of things. Here Sally Falk Moore's ideas are particularly relevant. In two striking pieces she made a strong case for what she terms 'processual anthropology' and the ethnography of the present (Moore, 1987, 1994). These are firmly situated in her conception of the importance of temporality in ways that dovetail well with Macintyre's sense of a properly historical anthropology. This is not reducible to the oft-adopted expedient of juxtaposing the past and the present:

Chopping up the social facts of fieldwork and putting them into two conceptual bins marked 'old' and 'new' is not the way to address the temporal problem. Such a sorting sounds as if it were saying something about sequence. But the effect of this classification is to remove the connections from view and treat time simply as an exercise in a dualistic categorization. (Moore, 1994, p. 371)

The point instead is that a processual attitude moves beyond retrospectives on the past and not only imagines the present as an emerging moment but also conceives of the present as a time from which the next moment will emerge. The focus is on the unfolding of events and on close inspection of the baggage that is brought to them and what is carried away afterwards (Moore, 1994, p. 371). 
This historical perspective sees the ethnography of the present as necessarily pointing towards the future. Events that claim our attention often sit at the intersection of different interests and aims and in that sense may be 'up for grabs' and connected to outcomes not clearly given in advance. Both conjunctural and contested, they may mark turnings along different pathways, foreclosing some possibilities and opening others.

Many of Moore's ideas were taken up by Liisa Malkki in an important piece on the ethnography of events as transitory phenomena (1997). Two parts of Malkki's account seem particularly relevant here. One is the question of the relation between news and culture. When PNG newspapers—and, after that, blogs and social media-became accessible on the internet in the 1990s, I was struck by the gap between what we as ethnographers wrote and the events we read about in the news. What struck Malkki as problematic was the relationship between ethnography and journalism, which often started and ended with an invidious comparison couched in ideas of comprehensiveness, depth and seriousness versus superficial, ephemeral and somewhat flighty coverage. But she suggested this gap was maintained by a self-conscious distancing between ethnographic traditions of regularity and durability against the irregular and evanescent. Here she agreed with Moore, arguing that an anthropology of the present is particularly important when it takes note of the unusual and even ephemeral, and on two counts-as analysis, and as witnessing. The former is important in understanding the historical process and the latter in appreciating what we increasingly have come to recognise as crisis. ${ }^{2}$

Without suggesting that ethnographers become journalists, Malkki argued for rethinking habitual distinctions between our respective tasks. Ethnographers of the present are concerned with accounts that make space for or are founded on the flow of events. However, this flow does not cease when the ethnographer leaves the field. In her case, she attempted to follow what was happening in and around the refugee camps she was working with, but this had to be done remotely and in a necessarily patchwork fashion, based on what she was able to gather from correspondence, phone calls, agency reports and news stories.

2 Here Kirsch is an honourable and early example (2006). 
In the remainder of this chapter, I turn to two cases in which unexpected events dramatically affected Telefolmin and others in the hinterland of PNG's Ok Tedi mine. In both instances, the terms of everyday life were disrupted and called into question; the term 'crisis' is not too strong to describe the situations in which people found themselves. The key events were wrenching but played out at different scales and with different dynamics. The first was an unprecedented outbreak of violent attacks against alleged witches in a rural village; the second was a prolonged period of drought across the region that led to the shutdown of the Ok Tedi mine and wholesale evacuation of the neighbouring town of Tabubil. These are the events referred to by the title of this chapter, and I have already published on them in some detail elsewhere (Jorgensen, 2014, 2016). But the burden of this chapter is to consider these events in light of their further trajectories and consequences - their aftermath. To anticipate my conclusions, I will argue that tracking events and their consequences after we leave the field provides us - even with imperfect information-a useful perspective on local futures and how they take shape.

At the time of my first fieldwork in 1974-75, the Ok Tedi mining project had gone from a source of occasional work clearing trails and drill pads to an exciting if vague presence on local horizons. A few years later, hundreds of men from Telefomin and surrounding areas were building the town of Tabubil; by the time I read Macintyre's Misima work, many had taken up permanent work at Ok Tedi and were soon followed by families who joined them in town. The two examples I discuss played out in a wider context in which the mining economy and the town of Tabubil had become familiar features of the landscape of local lives. For Telefolmin and many of their neighbours, the mining economy has been a source of prosperity and a range of benefits, including better access to educational and health services. But as we shall see, these benefits are not evenly distributed, even in relatively prosperous communities, nor is their continued availability assured. 


\section{Sorcery-related Killings in Telefomin}

While most Telefolmin regard a village as their home, for the past generation the rural economy has been supported by remittances from absent kin, ${ }^{3}$ many of whom fly home to visit their villages at Christmas. The events I discuss here occurred in the village of Talavip in late 2011, as people began arriving for the holidays. Some returned from various coastal towns, but most arrived from Tabubil (near the Ok Tedi mine) or from the Frieda River project to the north (see Figure 1). ${ }^{4}$ Among these was Samuel, who had planned to stand for parliament in the 2012 elections but died suddenly while awaiting his flight home. ${ }^{5}$ Not long afterwards, a group of village youths - described to me as 'The Boys'began what they called an 'Operation' to identify and punish those they suspected of killing Samuel by wiskrap ('witchcraft') (for further detail, see Jorgensen, 2014; see also Zimmer-Tamakoshi, this volume).

Operating from their 'men's house' on the margins of the village, The Boys enacted a program of intimidation and public torture as part of an effort to 'weed the garden' of those suspected of wiskrap. This culminated in the disappearance and murder of two men who had also returned home for Christmas. The Boys also accused a third man residing in Tabubil of wiskrap, but the latter's friends phoned to warn him not to come. ${ }^{6}$ He escaped, but his village house was ransacked, his family beaten and his sister raped.

These killings were unprecedented, in both the form that they took and in their degree of violence. The alleged wiskrap bears no discernible relationship to traditional (and long-discarded) varieties of sorcery and

3 This dependence intensified with the increasing size of bridewealth payments since the mid1980s (Jorgensen, 1993). A rough estimate of Telefolmin living in Tabubil and surrounding environs at the time runs to several hundred, including families of Ok Tedi Mining Ltd (OTML) employees who enjoyed company housing in town. Workers from Telefomin district have for some years formed the core of the OTML labour force (see Jorgensen, 2006; Jenkins, 2016a).

4 Tabubil is the town associated with the Ok Tedi mine, and serves as the administrative, logistical and commercial centre for the project, including an international airport.

5 His death was described by a villager as caused by a heart attack, with which Telefolmin are familiar (for further details, see the discussion of Haslam's visit to Telefomin below).

6 A killing of an accused youth in a neighbouring village (who had just won a scholarship to a coastal vocational school at this time) was also reported, but I have few details. There was also an attack against a villager employed by the government on the station who managed to escape (see below for further details). 
was said to be a recent import of Western origin. ${ }^{7}$ In fact, there was broad scepticism about the wiskrap allegations, which many regarded as spurious. Finally, Telefomin had possessed a 'quiet' reputation for decades; these killings were the most violent incident that had occurred since the 1953 'Telefomin Murders', in which two Australian patrol officers and two native police constables were killed (Craig, 1990). ${ }^{8}$

The Boys possessed little standing in the community; villagers referred to them as 'useless' (cf. McDougall, this volume). By most measures, they were disaffected and marginalised — unlike many elder brothers or uncles with mining jobs, The Boys were unemployed, largely unschooled and reportedly grew marijuana, which they both smoked and fed into the long-distance trade in drugs for guns (Alpers, 2005; Bell, 2006; Macintyre, 2008). ${ }^{9}$ The contrast between them and others was thrown into sharp relief at Christmas - the time when those with education or jobs returned to the village. I suspect that this fuelled The Boys' evident rage and displays of public sadism, including a penchant for forcing villagers to watch them torture their victims. Their effect on others was summed up by one villager in this way:

The Boys were 'terrorising' the community. They kept themselves apart in their haus man and everybody avoided them. At this time, people were afraid to go outside, especially at night. People didn't let their children go out and people didn't want to go to their gardens because they were afraid. Before they started one of their 'operations', they would strike the stones on the road with their weapons until sparks flew. They had axes, bushknives, sharpened iron rods and some guns. They didn't listen to or respect the elders, and they made war with (birua long) the community. The public servants on the station were so frightened that they quit work at 2:00 and stayed home. People relieved themselves in their houses rather than go outside. When people from other villages walked to the station, they would keep away from the village and take the other road by the school instead.

7 Traditional sorcery was not avenged through physical violence; people relied instead on unknown sorcerers in their midst to even scores on their behalf. It is important to note that such attacks were said to occur between villages, not within them —as in the present case. For further details, see Jorgensen (2014).

8 Only two homicides occurred in the valley over the nearly 60 years separating the two events.

9 Note that high school subsidies ended when the Telefomin District Development Agreement was terminated by the national government in 2004. From that point forward, rural families had to be selective about paying school fees. This was likely a factor in at least some young men's situations. 


\section{Contingency, Rupture, Change}

Retrospective analysis may detect a combination of sudden death, elections and a holiday gathering that highlighted pre-existing fault lines; however, the evidence suggests that, to most villagers, the torture and killings arrived out of the blue. This is about as unambiguous a case of rupture as one could hope to find-the violence surrounding the wiskrap accusations caught everyone (except the perpetrators) by surprise. ${ }^{10}$ However, while it is obvious that the attacks were radically new in Telefomin, it is difficult to see how this would count as change unless the attacks were repeated. To make that case, we must look beyond the events themselves and ask: will this happen again or have we seen the last of it? This, I would argue, was also the most pressing question facing the villagers among whom these events played out. ${ }^{11}$

We can get some sense of this by tracking how people responded to these events. During the time the attacks were taking place, the local police detachment was aware of what was happening but failed to intervene. Explanations offered after the fact included claims that more personnel would have been required, but that fuel budgets were insufficient to fly in additional staff from the provincial capital; the local lockup did not have the capacity to house the numbers involved in the attacks; and personnel and budgets were already stretched to the limit to provide security for the coming elections. Although the plausibility of each explanation is open to challenge, they serve as an indication that The Boys operated with effective impunity, as was common in many other parts of the country at the time.

In the period immediately after the killings, individuals who had been attacked or whose family members had been targeted effectively became exiles and sought safety by relocating elsewhere. A sense of unravelling is unmistakable in an email from one villager who travelled home for Christmas:

10 But the perpetrators were not surprised. A lengthier treatment would note that the attacks were entirely consistent with well-publicised patterns of sorcery-related killings in PNG, which reached a 20-year peak in 2011 (Forsyth et al., 2017). The torturers' playbook and talk of imported Western sorcery are quite familiar (see Englund \& Leach, 2000; Gibbs, 2012; Haley, 2008, 2010).

11 Here I must mention the serious and concerted efforts of colleagues to address the future of sorcery-related killings as a practical matter; these are informed by a backlog of experience and considered advice on policy and interventions (Forsyth \& Eves, 2015). Although I cannot pursue the matter here, Gibbs' (2015) outline of pragmatic responses matches quite closely the local efforts arrived at in Telefomin over the course of subsequent events. 
For the avip kasel (village people), they are not really okay ... the village especially is now at the state of breaking up the community, with each family [leaving] and moving to another location. Now the village is facing leadership crisis $\mathrm{coz}$ all the men are afraid. That's why my Christmas at home was not good. Anyway it's not a good story.

The widow of one victim moved to Mt Hagen, while his mother took his children into her care and established a separate household away from the village in the bush, where she felt safer. The government employee who was attacked at the station fled with his family to a neighbouring valley under the cover of darkness and subsequently moved to the provincial capital. The man in Tabubil who had been forewarned was able to fly his family to safety and flee with them to a distant town where he and his wife could find new employment. Yet another shifted with his family to a different valley in the region among a neighbouring ethnic group, where they have now settled. In each of these cases, empty and often derelict houses stand as reminders of those forced to seek safety elsewhere. The possibility of further attacks was not far from their minds. ${ }^{12}$

In the first half of 2012, the sister of Samuel (the man whose death The Boys claimed to avenge) also died suddenly of an apparent heart attack. Her family insisted on a post-mortem examination and paid for her body to be flown to the hospital in Tabubil for autopsy, which confirmed a heart attack as the cause of death. The family asked the physician in charge, Dr Nick Haslam, to present his findings to the haus krai (funeral) gathering in the village, which he did (Haslam, 2015; cf. Cox \& Phillips, 2015). His view was that this effort was effective, and it is noteworthy that Samuel's family went to extraordinary lengths to forestall further accusations or violence. Later that year, I received word of an intoxicated youth armed with a pistol who tried to disrupt a local funeral; I was told that the crowd shouted him down and drove him off, despite the fact that he was armed. Mourners reported him to local police, who confiscated his pistol, although he was later released without charge.

12 At least one other man who had been set upon by The Boys remained in the village but kept to himself and had few dealings with his neighbours, preferring to shift his church attendance to the congregation at the government station. 
After the 2012 elections, the new member of parliament (MP) for the area ordered the construction of a larger lockup facility at the station and recommended a strengthening of the local police detachment. That Christmas, he joined with a prominent villager in attempting to broker a reconciliation between the victims of the attacks and the families of The Boys, aiming to prevent any possible payback attempts. This was not successful - some of the victims' kin refused any attempt at reconciliation, while the family of another set the compensation demand so high that it would have been impossible to pay. When it was suggested that the possibility of charges against The Boys be dropped, one victim's family replied that their wish was that 'the law should take its course'.

After many delays, homicide charges were brought against three of The Boys; they were arrested and transported to the provincial capital to appear in court in 2014. The charges and witness testimony were heard in national court, but the presiding judge found that there was no case to answer, because the victims' bodies had not been found: the defendants were discharged.

Now, nearly eight years later, the 2017 election has taken place with no violence reported in Telefomin, nor have I received any word of further attacks associated with wiskrap accusations of any sort (and nor have I heard anything further about The Boys). While the future remains open, it appears that such accusations and attacks-a variant of PNG's sorcery-related killing epidemic — have not become established as a 'local practice'. To the extent that this is true, it seems likely to be the result of the efforts of Samuel's family and the local MP to put the 2011 killings behind them.

\section{If There is a Moral to this Story ...}

$\ldots$ it is that contingent events may leave permanent traces without becoming precedents or being normalised. People died, empty houses remain and villagers have departed in the wake of The Boys' violencenobody is likely to discount the after-effects of their rampage. But facing the possibility of a darker future, Samuel's family and the new MP (among others) undertook their own efforts at repair whose most apparent effect may be the welcome absence of discernible change. 


\section{The El Niño Drought and the Ok Tedi Shutdown}

In 2015 I returned briefly to PNG to pursue mobile phone research when the El Niño drought intervened. By mid-2015 conditions were deteriorating in many parts of the country and my main concern quickly became reporting on the drought's impact on the Min people straddling the boundary of West Sepik (Sandaun) and Western Provinces. This was part of a broader effort by Bryant Allen, Mike Bourke and others to gather information on the drought and responses to it across PNG. The data was compiled, mapped and forwarded to government and non-governmental agencies in an effort to help coordinate relief efforts (Bourke et al., 2016). At the end of September, Paul Barker presented my preliminary report at the Institute of National Affairs in Port Moresby as I made my way back to Canada. This report became the nucleus of my subsequent paper on the drought and its impact (Jorgensen, 2016).

Although the effects were not as severe as in some parts of the country, the drought's consequences for Min people were complicated by the fact that they live in the Ok Tedi hinterland centred on the mine and the town of Tabubil (Jorgensen, 1996, 2006; see Figure 1). As the residential and logistical hub for Ok Tedi, Tabubil had become the largest town in western PNG, with a population of over 18,000 in 2009 (National Statistical Office, 2009). ${ }^{13}$ Both the town and the mine depend on shipping via the Fly River port of Kiunga for fuel, food and supplies, and low water had made the river unnavigable.

13 Population figures for Tabubil are notoriously inconsistent. Compare, for example, figures in Filer and Jenkins (2017, p. 242) with figures in two reports by the National Statistical Office (2014, 2009, conducted in collaboration with the PNG Sustainable Development Program). Carr and Filer put the 2009 population of the town and environs at around 23,000, whereas Howes and Kwa's assessment puts the population of Tabubil at 25,000, 'including adjacent settlements and villages' (Howes \& Kwa, 2011, p. 15). I use the 2009 National Statistical Office figures here, which include four adjacent villages and one migrant settlement; these lie outside the formal boundaries of OTML's lease, but comprise part of Tabubil's everyday network of activity. The National Statistical Office lists the total number of households in Tabubil as 2,673. 


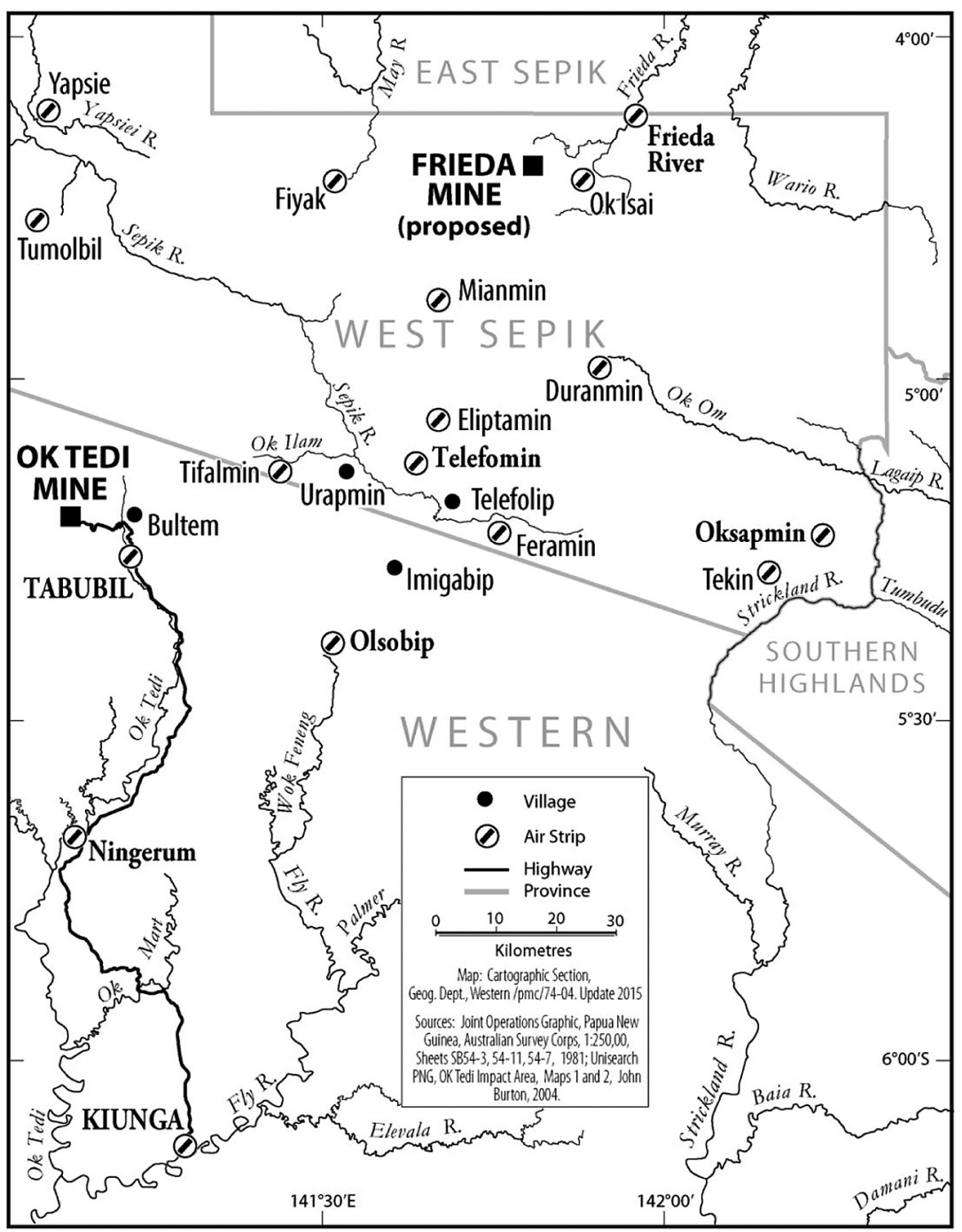

Figure 1: The Ok Tedi hinterland.

Cut off and unable to deliver ore to market, OTML declared force majeure and suspended operations in early August 2015. To ease pressure on supplies, workers and their families were sent to their home areas across PNG pending an end to the crisis. The departure of an estimated 2,000 families (James, 2017) amounted to a diaspora that affected the Ok Tedi hinterland and beyond, amplifying pressures and dislocations in the 
drought-affected communities to which they returned. In the hinterland, the evacuation was a solution to problems at Ok Tedi; however, it became a source of problems for rural people who were already struggling.

After my return to Canada I tracked local conditions via phone, text messaging and social media. In October 2015 I submitted a manuscriptwith a postscript on updates-to Oceania. The reviewers were receptive and argued for speedy publication in view of the ongoing crisis. However, there was to be an important revision: noting my previous update, one of the reviewers asked for a further update on events since October. The resulting addition amounted to a postscript to a postscript (Jorgensen, 2016, pp. 35-36), the gist of which may be summarised in two sentences from a statement made by OTML in December. Under the title 'Coming back to OTML — what's different?' CEO Peter Graham said:

As the majority of employees will be FIFO, the residential makeup of Tabubil town will change. Generally families will not be onsite and employees will be in dongas and share accommodation. (Ok Tedi Mining Limited [OTML], 2015c)

\section{Ok Tedi, FIFO and Tabubil}

When the evacuation began in August, the Papua New Guinea PostCourier's Jeffrey Elapa reported that:

Many police men from MacGregor Barrack MS [Mobile Squad] 1 have joined their friends from MS 19 to take part in the eviction of the employees and their families from company houses in Tabubil and Kiunga, putting them on the plane back to their point of hire or home provinces. (Elapa, 2015a) ${ }^{14}$

The evacuation and shutdown immediately drew critical reactions, including a declaration in Parliament by the Telefomin MP that the layoff of employees and contractors was unjust and that OTML management failed to give advance warning of the repatriation exercise (Gunga, 2015; cf. Mann, 2015; Peter, 2015).

Despite these reactions, there was a certain familiarity with the process of shutting down the mine and evacuating Tabubil_OTML did the same in the El Niño drought of 1997-98, a suspension that lasted roughly seven

14 In another report, Elapa stated that over 200 police personnel assisted the eviction and that an estimated 300 families left the OTML Kiunga compound at the same time (2015b). 
months as well. But there was a key difference: arriving near the end of the drought, OTML's December announcement was an unprecedented game-changer. The plainest meaning was that those families who had been sent to home areas because of the drought were now to stay where they were after the drought had passed. Even if the mine shutdown was temporary, their repatriation was intended to be permanent- they had been evicted from Tabubil, not merely evacuated.

When interviewed, OTML's CEO claimed that FIFO was the dominant practice in the mining industry and was clearly preferred by operators; from this point of view, OTML had been out of step with the industry and was simply catching up (Business Advantage Papua New Guinea, 2015; Garrett, 2015). However, arguments and negotiations about FIFO are not new in PNG (see e.g. Bainton, 2010; Gerritsen \& Macintyre 1991; Jackson, 1988; McGavin, Jones \& Imbun, 2001). ${ }^{15}$ FIFO was the subject of early negotiations surrounding the establishment of $\mathrm{Ok}$ Tedi, and the government position stressed national participation in a project with the state as an equity partner. As early as 1978 government negotiators emphasised the importance of establishing a township that was open to local people. Beyond that, there was a stated interest in limiting the ratio of single to married mine employees and in the provision of training facilities to enable the participation of local people in the project (Jackson, Emerson \& Welsch, 1980; Pintz, 1984).

The Ok Tedi impact study argued that typical models of enclave development were self-destructive, with tensions between local people and the outside workforce at the Bougainville mine serving as a negative example (Jackson et al., 1980; cf. Nash \& Ogan, 1990). The aim was to integrate local people with the project rather than insulate them from it; an open township was integral to this position. There was also a preference for family settlement: plans for Tabubil assumed two dependents per employee, with married employees predominating over singles. The reasoning behind this was evident in fears regarding what a massive influx of single outsiders might bring: 'rascals, involvement with local women and brawling as a result of drinking' (Jackson et al., 1980, p. 274; cf. Bainton \& Banks, 2018).

15 Public debates about FIFO have recently played out in PNG newspapers and social media. See, for example, Kenneth (2019), Vari (2019), Kepmewato (2019) and a series of articles in The National (e.g. 2013, 2014, 2018a, 2018b). 
The state's plan for Tabubil as a residential community prevailed; Tabubil was to offer employment in addition to medical and educational services for the surrounding region. Access to family housing was an important issue for workers and became an element of early labour strife. In 1988 striking workers supported their demands for housing by digging up roads, blocking airstrips and cutting telephone lines (Jackson, 1993, p. 187). OTML management had contemplated declaring force majeure but resolved the issue and agreed to build an additional 200 family houses over the following 18 months. Family housing thus has a history in labour relations at Ok Tedi: all the more striking, then, that OTML decided to eliminate such accommodation after a generation of employees' families had made their homes there.

\section{From Tabubil Futures to FIFO}

Ok Tedi was PNG's first large post-independence mine and, in its haste to bring it on stream, the state permitted it to commence operations without a tailings dam. Massive quantities of mining waste were dumped in the Ok Tedi River, which led to a lawsuit by local people and a transnational coalition against the operator and chief shareholder (BHP). The case was brought to court in Melbourne amid great publicity and did not go well for BHP. The result was an out-of-court settlement for damages (Banks \& Ballard, 1997) that ultimately led to BHP's 2002 exit from the project to avoid future liability. Subsequent legislation governing Ok Tedi permitted the mine to operate until 2009 and then to 2015; in 2011-12, OTML was preparing a submission to extend mine operation to 2025 (see Carr \& Filer, 2011; Jenkins, 2016a). Such plans required approval by landowners and villages along the Fly River that had been affected by the mine's pollution, and had also to be approved by the PNG government.

When BHP left the project, its shares were vested in the PNG Sustainable Development Program (PNGSDP), a not-for-profit company whose mandate is to 'support and promote sustainable development through initiatives that will benefit the people before and after closure of the Ok Tedi Mine' (PNGSDP, 2019). Since then, PNGSDP had funded numerous local development projects in Western Province and the rest of PNG. As the mine's majority shareholder, PNGSDP also had a strong voice in the direction of OTML. When Inmet, OTML's last private shareholder, exited Ok Tedi in 2011, the mine's remaining shareholders were PNGSDP (64 per cent) and the state of PNG (36 per cent). Nigel 
Parker, OTML's CEO, argued that this altered the calculus of corporate priorities. He observed that when Inmet was a shareholder, there was a mix of the commercial mandate with the social mandate:

Inmet were very good in the social mandate side of it but now Inmet has exited it is full social mandate so everything we do has a focus on the Papua New Guinean people, what we can deliver to the economy, to the peoples of the Western Province and, of course, to a wider group of people that are not just impacted by the mine. (Garrett, 2013, emphasis added)

In line with these statements, OTML and PNGSDP developed plans for Western Province after mine closure. ${ }^{16}$ These included the Tabubil Futures project, which aimed to transform Tabubil into a mixed-economy town with 'a college in the clouds' as its centrepiece: the Star Mountains Institute of Technology (Business Advantage Papua New Guinea, 2012a; Jenkins, 2016a; Nalu, 2012; PNGSDP, 2011).

Things did not go smoothly in 2013, however, and Parker described the year as 'like riding a tiger' (Wilkins, 2013). Profits fell sharply due to a drop in copper prices, declining ore grades and ageing equipment. More importantly, 2013 saw another change of ownership as the recently elected O'Neill government expropriated PNGSDP and took control of OTML and its assets (Howes, 2013a, 2013b). This unsettled period marked a shift in OTML's fundamental orientation.

In 2011 and 2012, OTML's public statements stressed corporate social responsibility (Business Advantage Papua New Guinea, 2012b, 2012c). ${ }^{17}$ However, after the expropriation, OTML emphasised what Parker called the commercial mandate:

The new OTML vision is: We are a sustainable, efficient and well-regarded operating company that delivers value to all our stakeholders. The new mission is: We mine gold, silver, and copper from PNG reserves. (OTML, 2013, p. 6)

16 PNGSDP's most successful project of this period was the 2011 construction of a telecom tower network that provided mobile phone coverage to most of the population of Western Province. For information on the relationship between OTML and PNGSDP, in addition to mine extension plans, see Carr and Filer (2011), Filer and Jenkins (2017), Jenkins (2016a), Howes (2013b) and Morauta (2014). I discuss the crucial role played by PNGSDP's Long Term Fund (LTF) below.

17 For example, OTML's 2012 annual review contained the following vision statement: 'our hope and our vision is to empower local communities such that they are healthy, educated and economically diversified' (OTML, 2012, p. 7). 
OTML's 2013 annual review mentions plans for Tabubil Futures for the following year; however, the 2014 review merely reported that no progress had been made 'due to legislative delays' (OTML, 2014, p. 23). Tabubil Futures disappeared altogether from subsequent OTML reports without further comment. ${ }^{18}$

During this time OTML embarked on a program of restructuring and by the end of 2014 had cut a third of its workforce and introduced new rosters for those who remained (James, 2017; OTML, 2013, 2014; see also Jenkins, 2016b, p. 11). ${ }^{19}$ The groundwork for these changes was laid in 2013, when a Brisbane consulting firm was hired to produce streamlined work rosters to extend mine life to 2025 (Middleton, 2014; Shiftwork Solutions, 2014). Here, however, it is important to note that their brief was not only to work towards more efficient rosters but also to 'reduce impacts on the local economy associated with the termination of a residential mine in a remote location' (Middleton, 2014). One of their findings was that existing rosters resulted in 'the character of the site to be more residential than FIFO' (Middleton, 2014). What is implied, but left unstated, is that a residential workforce presented a problem. One remedy was to revise accommodation arrangements; these appear in OTML's 2014 annual review as new single accommodation blocks for FIFO staff (OTML, 2014, pp. 23, 46). ${ }^{20}$

Phrased as a matter of efficient timetabling and employees' working conditions, the rostering project nonetheless reveals a preoccupation with FIFO and Tabubil's post-closure residential configuration. Parker addressed the relationship between FIFO and the township in an article that appeared at the same time (Oxford Business Group, 2014). Although OTML built Tabubil with over 1,000 single-family houses for residential employees, Parker suggested that the FIFO alternative would be attractive to employees from other parts of PNG. Arguing that his main concern was the viability of a post-mining township, he also claimed that special purpose mining leases_-as at Tabubil—were unsuitable for long-term development. He went on to say that sustaining a township

18 There was no OTML annual review for 2015, though the 2016 review includes some data from 2015. Note that the eclipse of the social mandate at Ok Tedi parallels what Kemp and Owen (2018) have termed 'corporate refusal'.

19 Most mines operate on a 24/7 basis, which makes shift timetabling (rostering) crucial for smooth operations. Shiftwork Solutions reported that Ok Tedi rosters were relatively uncoordinated and chaotic, which made flight schedules for FIFO employees particularly complicated and costly.

20 These became known as the 'Parker Dongas'. Note the move away from family housing. 
requires massive investment and concluded by asking, 'whether a resource company should be required to develop a supportive township'. Although he stopped short of endorsing FIFO as a transition to a post-mining Tabubil, the door to that option had clearly been opened.

\section{Implementing FIFO}

When Peter Graham succeeded Parker as CEO in May 2015, an expanded FIFO model was on the table. Recalling that time, Graham noted the declaration of force majeure and the relocation of employees' families as his first order of business. This was followed by further retrenchments, new rosters and the move from a residential to a FIFO operation (James, 2017). Shortly after the FIFO announcement, he explained that 'being residential just costs a lot to run a town, and providing all of the services and maintaining the houses and providing schooling for residents' families ... [are] just a cost the business can't afford' (Garrett, 2015). He later argued that Ok Tedi was 'on death row', but that cost-cutting had extended the mine's future, bringing it to a sweet spot (James, 2018).

The drought provided OTML with the opportunity to finesse the FIFO transition without the complications of dealing with a resident population in Tabubil. On return to work in 2016 all employees had to agree to new roster assignments and conditions of employment before being re-hired. ${ }^{21}$ The FIFO transition was in this sense a 'done deal' by the time that operations resumed (Australian Broadcasting Corporation, 2016). Despite this, there existed signs of dissatisfaction among returning workers. One assessed the new situation this way:

Very hectic working environment, understaffed and overloaded. The company was once one of the very best employer until recently taken over by the government and was forced to undergo a lot of changes including cut in work force, restructure, ceased of all incentives, change of rosters and do away with residential status to FIFO. These are changes that are really affecting my interest and my approach to the company. (Indeed, 2019)

21 OTML reports that 99 per cent of their employees accepted offers under these terms (2016, p. 3). 
Another said:

Ok Tedi Mining Limited was once a company that most people would wish to work with. The operation was a residential type where employees are accommodated with their families onsite and most staff gets weekend offs accept (sic) the shift workers who are compensated very well. Things have changed and the operation is now a FIFO operation where the employees were told to move their families out of the mining township to their point of hire/ origin. I am currently on 4 week and 2 weeks off. (Indeed, 2019)

Area residents welcomed the return of OTML employees but noted that many came merely to pack belongings and leave for good.

Over the following year, there were general complaints about abandoned buildings or disused facilities (e.g. the golf club or tennis courts); some described Tabubil as a ghost town, even two years after the drought. However, these observations were juxtaposed with other comments that insisted that families had returned and moved back into their former houses. One social media post helped to put these discrepant parts of the picture together:

Mate it's like a ghost town all employees are on FIFO and the houses are given to local employees only ... almost half the town has empty houses ... now it's no more the Tabubil that we used to know.

These remarks suggest a slippage between stated policies and the actually existing FIFO arrangements. Official announcements stressed that the FIFO policy covered all employees (OTML, 2015c, 2016, p. 42). But in April 2016 it emerged that workers whose point of hire was Tabubil or nearby areas of the North Fly and Telefomin Districts ${ }^{22}$ were allowed to return to family housing for a rental fee (Papua New Guinea Resources, 2016). The reason given was the desire to minimise travel time for workers on short-cycle rosters, and in 2017 this number accounted for more than 400 employees and their families (OTML, 2017, p. 44).

Housing reappeared as a labour issue in early 2018, when around 100 workers staged a sit-down protest over roster changes that they had been disputing since operations resumed. OTML management sacked them within hours and flew them out of Tabubil the following day (Mauludu,

22 This was known as the 'Preferred Area' (see Jenkins, 2016a). 
2018a, 2018b). ${ }^{23}$ This was not the end of it however: six months later OTML and the employees' union signed a new contract that encompassed 'benefits for the workers such as housing' (Gware, 2018). This agreement allowed 'employees who work the three-week roster ${ }^{24}$ eligibility to reside in Tabubil ... As a result, it is expected that an additional 110 families will relocate to Tabubil during 2019' (OTML, 2018, p. 46; cf. EMTV, 2018).

By January 2019 the number of preferred-area families at Tabubil had risen to 420. Together with the 110 additional families, a total of 530 employees' families resided in company housing early in the year (OTML, 2018 , p. 46). This accounts for about one-third of the current workforce, suggesting that done deal or not, OTML's move to full-on FIFO lost ground within two years of its launch.

\section{Tabubil Futures Redux?}

The most consequential outcome of 2015 for many in Ok Tedi's hinterland was the shift to FIFO, and the event that set this in motion was not the El Niño drought, but the government takeover of OTML. Local views see FIFO as a threat to Tabubil and, with it, the future of the North Fly region. Social media commentary highlighted the damage that closing down Tabubil would inflict on the regional economy and took aim at the premise that the mine's viability hinged upon scaling back support for the town. Others argued that the mine owed its existence to a commitment to the North Fly region in agreements that permitted OTML to operate at all (as discussed above; cf. Banks \& Ballard, 1997; Filer \& Jenkins, 2017): 'closing down the township would be against the spirit of the mine continuation' (Pinen, 2015).

Phillipa Jenkins, much of whose work focused on mine continuation negotiations, registered similar misgivings based on her research before the drought. Considering Tabubil's viability after the state stripped PNGSDP of its equity, she went on to say that:

23 North Fly MP James Donald unsuccessfully called for the Mines Minister to intervene (Mou, 2018; Poriambep, 2018). OTML's public response pointed out that the employees' contracts included 'a 10 per cent wage increase on restart after dry weather associated with a new FIFO roster' (Business and Human Rights Resource Centre, 2018).

24 That is, the short-cycle roster. 
With this national government takeover of OTML, the future sustainability of Tabubil and the other villages above Ningerum becomes less likely. The people of Western Province are unlikely to benefit at all from the national government's appropriation of PNGSDP's share in OTML. (2016a, p. 133; emphasis added)

What she perceived clearly was that the expropriation was more than a simple assertion of nationalistic control; it signalled a fundamental change in the relationship between the mine and the surrounding population.

Ok Tedi's takeover occurred against the backdrop of a burgeoning debt load that threatened state finances. Capturing the entirety of Ok Tedi's revenue stream was an important motivation, and although the mine had no private shareholders, the state behaved as any privately owned mining company might: it sought to extract as much value as possible by cutting costs to enhance the bottom line. In the process, the FIFO strategy effectively declared the state's interests and those of the mine's hinterland to be at odds.

In the overall scheme of things, however, OTML's dividends may have been a sideshow for the O'Neill government. From the beginning it was evident that the government's attention was focused on a much bigger target: the USD 1.4 billion Long Term Fund (LTF) established by PNGSDP. Since its founding in 2002, two-thirds of PNGSDP's dividends were allocated to the LTF; these were to become available to the people of Western Province after mine closure. This fund was invested in low-risk securities administered from Singapore, where PNGSDP was incorporated - a fact intended to place the assets beyond the reach of PNG politicians (Howes, 2013b; Morauta, 2014). One of the government's first actions following the takeover was an attempt to seize these funds, leading to prolonged litigation in Singapore (Howes, 2013a, 2013b; McLeod, 2019; PNGSDP, 2019).

As of 2019 the future of Tabubil looked as uncertain as ever, but the year also held surprises for the O'Neill government. In early April the Singapore courts found in PNGSDP's favour and rejected the state's claim to the LTF. Before the month was out, Prime Minister O'Neill resigned; James Marape became PNG's new prime minister at the start of May. In mid-June, Marape travelled to Singapore and, a week later, visited Tabubil. There he met with local leaders and OTML executives and gave a public speech in which he put both OTML and the Western 
Provincial Government on notice. He took them and previous national governments to task, arguing that through the Ok Tedi mine the people of Western Province had helped the country to generate hundreds of millions in revenue but had received little benefit in return. He charged Provincial Governor Awi Yoto with the responsibility for improving the situation through a number of measures, including finding common ground with PNGSDP and putting an end to FIFO for OTML workers (Gerega, 2019).

While it would be unwise to place too much credence in the contents of a single speech, Marape's position seemed to have been directly aimed at repairing the relationship between OTML and the people of Western Province-and especially Tabubil and the North Fly-by pushing for specific measures. One indicator may be the following month's announcement that OTML, through the state's tax credit scheme, was undertaking to seal the $136 \mathrm{~km}$ highway connecting Tabubil to Kiunga for the first time since it was built in 1981 (Loop Business, 2019). At a cost of an estimated PGK 100 million and a construction schedule of three years, the project suggests that Tabubil does indeed have a future beyond the current mine termination date of 2025 .

\section{On the Mining Economy and Inequalities in Ok Tedi's Hinterland}

In closing, I venture a few remarks on this volume's theme of inequality. We have known for some time that large resource projects produce new forms of inclusion, exclusion and marginalisation at different scales (see e.g. Ballard \& Banks, 2003; Jacka, 2001, 2015; Main, this volume), and much of this chapter is set within the context of inequalities arising from the $\mathrm{Ok}$ Tedi mine at both local and regional levels. ${ }^{25}$ The exiles of this chapter's title are families forced to leave their home village in the face of The Boys' violence, while the empty houses are those left behind by workers and families who were evicted from Tabubil in OTML's FIFO scheme. The events surrounding these circumstances can be traced to the distribution of advantage and disadvantage in the regional mining economy.

25 One obvious dimension of inequality at Ok Tedi is the contrast between the people in the foothills and mountains of the hinterland and those who have been subject to the environmental effects of the mine on downstream portions of the Ok Tedi and Fly River systems. I have discussed these matters in more detail elsewhere (Jorgensen, 2006; see also Kirsch, 2006). 
In the case of The Boys, inequalities at the local level are evident and clearly fuelled the animus they showed in their attacks. In this they have much in common with disenfranchised Ipili youth, who may become self-styled 'Rambos' (guns for hire) on the fringes of the Porgera mine (Jacka, 2019). Unlike the latter, however, The Boys' violence was directed within their own community rather than in intertribal conflicts. In Telefomin the axis of inequality manifested itself most powerfully at close range, rather than following traditional lines of political cleavage (see note 7 above). This difference notwithstanding, however, both the Ipili and Telefol cases also hint at emerging issues of intergenerational equity (Jorgensen, 2019, pp. 109-110) — a factor that was long ago identified by Filer as a feature underlying aspects of the Bougainville conflict (1990). This would suggest that, as at Bougainville, inequality may develop relatively slowly over time, as fissures grow between early beneficiaries and disadvantaged successors (see also Bainton \& Macintyre, 2016).

Less obvious, perhaps, is the way that inequality figures in understanding the dynamics of OTML's FIFO policies. Here the most telling form of inequality is that between the national government and the people of Ok Tedi's hinterland, who-despite a range of legal provisions, agreements and consultations-have had little say in large decisions affecting their lives. This structural inequality is similar to what we are used to seeing in the relationship between transnational corporate developers and local people, with the added irony that-because the state itself is now the developer-the state's role as protector of local interests is compromised by interests of its own. In the case of FIFO, the material consequences of closing Tabubil raised the prospect of permanent regional marginalisation: an entrenchment of inequality through what Ferguson has termed the 'global disconnect' (1999).

Having said this, however, this chapter's larger point is that the aftermath of these events has not yet run its course. As we have seen, apparent changes are themselves subject to change: FIFO policies became attenuated, a terminal date for Ok Tedi now appears more notional than real, and the question of the LTF and its disposition at the end of mine life remains open. An ethnography of the present in the Ok Tedi hinterland will have to be one from which the region's future can be seen to emerge. 


\section{Postscript: On Doing Remote Ethnography of the Present (November 2019)}

The events I have focused on were disruptive in both the technical sense of unsettling things as they were and in the human sense of disturbing people's lives. My intent in writing this chapter was in the spirit of Malkki's remarks, which is to provide both analysis and a form of witnessing. To close, I'd like to venture some brief comments on doing ethnography at a distance while events continued to unfold.

These two sets of events posed the question: what happens next? Email and SMS contacts with villagers were crucial in tracking the aftermath of The Boys' violence after leaving the field, and I also became a close follower of news reports (though these yielded little). ${ }^{26}$ But the single most helpful contact occurred by chance, when Nick Haslam emailed me to discuss the post-mortem and the funeral of Samuel's sister. What I came to know was largely adventitious and depended upon Haslam's intervention.

Things were different in the case of Ok Tedi's shift to FIFO, not least because the nature of the event itself was not immediately evident. The move to FIFO came as a surprise to workers and families but was in fact a decision by OTML management that had been contemplated well in advance of the drought that provided cover for it. What had been a story of drought and recovery became a story of displacement instead. But the details only became clear after following OTML documents, published interviews with OTML executives, news reports and social media commentary. My dependence on journalistic and internet sources underscores both the possibility and difficulty of following events and subsequent developments in absentia.

I would also argue that providing an account of the sources of the FIFO transition brings something into view that was always significant but rarely discussed-the importance of national policy on Ok Tedi in shaping the future of Tabubil and its hinterland. Tabubil's urban infrastructure, sealed airstrip, communications network and road connection to Kiunga provide not only a gateway to the Ok Tedi mine: it is also the only reliable portal to the outside world for the people of the northern reaches of Western

26 Contacts with colleagues were also useful, particularly Richard Eves, Philip Gibbs, Tom Strong and (especially) Miranda Forsyth. 
Province. ${ }^{27}$ Anything that jeopardises Tabubil's viability threatens a 'return of remoteness' for the entire region and guarantees perpetual 'Last Place' (las ples) status for its inhabitants (cf. Saxer \& Andersson, 2019). For this to happen in the aftermath of Ok Tedi's closure would represent an unacceptable externalisation of risks and costs by an enterprise that is owned by the state in the name of the people of PNG (cf. Bainton \& Holcombe, 2018). Being able to trace the links back to the state's takeover counts as a vindication of the approach taken here.

Having said this, what about events on the ground and the present state of play in Tabubil? One of my frustrations is that most of my Telefol contacts who lived in Tabubil did not return there after the shift to FIFO; therefore, I have little access to first-hand accounts of local conditions, aside from the social media commentary alluded to above. What we do know is that Ok Tedi is widely expected to operate through at least 2030, although this will require a further continuation agreement. ${ }^{28}$ In addition to the sealing of the Tabubil-Kiunga highway, there are roads currently being extended out from Tabubil east to Olsobip and north to Telefomin (Elapa, 2019). All of this would seem to suggest that Tabubil will remain a regional hub for the foreseeable future. As to life in Tabubil, two unexpected sources of information provided hopeful news in the latter part of 2019. A friend working in parliamentary circles in Port Moresby reported that 'by next year 2020 all OTML employees will be going back with families-it has started already'. Not long after this, I learned that Emma Gilberthorpe was working on a project in one of Tabubil's peri-urban villages. In response to my queries, she replied:

It's quite amazing ... They rent the houses out to local people. Schools are bustling. There are projects going on, rice farm, fish farm, chicken farm. It's really looking good ... The Min highway is being built. It has passed Bolangun already.

\section{Second Postscript (May 2020)}

In the five months since the previous postscript was written, the situation in the Ok Tedi hinterland has dramatically changed. The World Health Organization declared the coronavirus pandemic in February and, in

27 This is especially so given the closure of smaller airstrips in the northern part of Western Province, as at Olsobip and Nomad (see Knauft, 2019).

28 This scenario is corroborated in part by the fact that OTML recently invested in upgrading and relocating one of the mine's crushers. 
March, the PNG government announced a State of Emergency (SoE) that was subsequently extended to the end of June. The strategy was to impede the virus' spread by imposing travel restrictions, closing schools and universities, prohibiting large gatherings and enforcing a general lockdown in urban areas (Lyons, 2020).

National borders were an immediate focus of concern; ports and international airports were closed and security assumed particular importance regarding Indonesia's border with PNG's West Sepik and Western Provinces (Blades, 2020). Politicians called for new or expanded border posts at Tumolbil and Yapsiei (Nanau, 2020) and at least one provincial governor called for enforcement on a 'shoot to kill' basis along the border (Radio New Zealand, 2020a).

Border anxieties were not confined to politicians: news of coronavirus deaths in Indonesia led scores of villagers from Tumolbil and Yapsiei to flee to Ok Isai, roughly $60 \mathrm{~km}$ to the east (see Figure 1). ${ }^{29}$ At Tabubil, two employees returning from overseas leave were suspected to be infected with coronavirus and were quarantined pending (negative) testing (Post-Courier, 2020a). ${ }^{30}$ Not long after, three traditional border-crossers who tested positive for the virus were intercepted at Bige, along the $\mathrm{Ok}$ Tedi River, between Tabubil and Kiunga.

The meaning of these developments for the people of Tabubil and the hinterland was not immediately clear. One result was an increase in army deployment at both Kiunga and Tabubil, and OTML security established checkpoints along the Kiunga-Tabubil Highway to prevent outsiders entering the area (Loop Business, 2020a, 2020b). Strengthened travel restrictions requiring government authorisation for flights out of both towns underscored the point that the North Fly region was seen not only as vulnerable but also as a potential threat to the rest of the country (Radio New Zealand, 2020b, 2020c).

There are also safety issues about large industrial sites such as the mine, and these couldn't help but conjure the possibility of a replay of the El Niño shutdown. In the face of such concerns, OTML CEO Graham announced that mine production would continue during the SoE, arguing that sufficient safety measures were already in place.

29 Coronavirus fears fuelled new or borrowed conspiracy theories, with quack cures and apocalyptic pronouncements flooding social media.

30 Elsewhere, calls for an end to FIFO were repeated (Papua New Guinea Post-Courier, 2020b). 
In late April Tabubil went into enforced lockdown: all entry points were barricaded, and inspections were conducted to locate unofficial residents or visitors, who were required to leave. ${ }^{31}$ All employees' families were given the option of remaining in OTML housing or returning to their villages, and workers who left to join families when the SoE was imposed were stood down for the duration (Esila, 2020). In the meantime, widespread testing and contact tracing were announced for remaining workers and their resident families, with reports that employees who tested positive would stand down but continue to draw full pay. ${ }^{32}$

Despite these efforts, it is not clear that the mine will be able to continue to operate, and my optimism about Tabubil's future at the end of last November may have been premature. Among other things, the closure of the port of Kiunga suggests that there may be a limited capacity to absorb and stockpile further production. Beyond this, there is no guarantee that Tabubil will be able to remain free of the coronavirus, nor even that it will not become a hotspot for the dissemination of further outbreaks across the hinterland. The history of clandestine entry to Tabubil associated with the traffic in marijuana, guns or even betel nut makes it clear that there are unofficial routes of access to the town. There is no reason to believe that keeping infection out will be any more reliable than it has proven to be anywhere else. If that is the case, the future of the mine, the town and the region may be up for grabs.

The irony of Tabubil's situation —and that of its hinterland - is one that it shares with many other parts of the globe today. Where its future was once predicated on its connections to the world at large, its continued viability seems - at least in the short run-to depend on its insulation from that same world. Its success in escaping Last Place remoteness may come at a high price. Spillover is the pandemic's signature process, and nobody can yet say where it will all lead. This is as true for me, writing from the security of my home in the sixth week of Canadian lockdown, as it is for the people of Tabubil and its environs. The best one can do at present is wish them (and one another) well.

31 Local contacts suggest that those wishing to enter Tabubil from outside are housed in tents at town entrances pending results of COVID-19 testing; however, I have been unable to confirm this. 32 I was told that those who tested positive would not be permitted to return to their rural villages until they had undergone a 14-day quarantine and later tested negative. 


\section{Acknowledgements}

This chapter developed from a paper I wrote for Aletta Biersack's 2018 American Anthropological Association panel on modelling change under the title 'Expectations of permanence? Events, exiles and empty houses in the Ok Tedi hinterland'. The panel provided a testbed for some of the ideas presented here, and I am grateful to Aletta for her comments and suggestions concerning them. I also owe much to each of the following for suggestions and information (but none of them is to blame for my use of their help): Nick Bainton, Snoky Bowin, John Cox, Julian Craig, Terry Dagayok, Yon Dagayok, Robert Dripal, Colin Filer, Miranda Forsyth, Don Gardner, Emma Gilberthorpe, Nick Haslam, Phillipa Jenkins, Michael Main, Debra McDougall, Jackson Pinen, Gons Samson, Simon Soltumnok, Steve Sumengim, Musje Werror and Mike Wesch. Finally, Imke Jorgensen provided candid feedback in addition to an indispensable leavening of good humour and good sense.

\section{References}

Alpers, P. (2005). Gun-running in Papua New Guinea: From arrows to assault weapons in the Southern Highlands. Geneva, Switzerland: Small Arms Survey. Retrieved from smallarmssurvey.org/fileadmin/docs/C-Special-reports/SASSR05-Papua-New-Guinea.pdf

Australian Broadcasting Corporation. (2016, 8 February). Ok Tedi to resume next month after El Niño suspension [broadcast]. ABC News Pacific Beat. Retrieved from abc.net.au/radio-australia/programs/pacificbeat/ok-tedi-toresume-operations-next-month-after-el/7148028

Bainton, N. (2010). The Libir destiny: Cultural responses to mining in Melanesia. Canberra, ACT: ANU E Press. doi.org/10.22459/LD.10.2010

Bainton, N. \& Banks, G. (2018). Land and access: A framework for analysing mining, migration and development in Melanesia. Sustainable Development, 26(5), 450-460.

Bainton, N. \& Holcombe, S. (2018). A critical review of the social aspects of mine closure. Resources Policy, 59, 468-478. 
Bainton, N. \& Macintyre, M. (2016). Mortuary ritual and mining riches in Island Melanesia. In D. Lipset \& E. Silverman (Eds), Mortuary dialogues: Death ritual and the reproduction of moral community in Pacific modernities (pp. 110-132). New York, NY: Berghahn Books.

Ballard, C. \& Banks, G. (2003). Resource wars: The anthropology of mining. Annual Review of Anthropology, 32, 297-313.

Banks, G. \& Ballard, C. (Eds). (1997). The Ok Tedi settlement: Issues, outcomes and implications. Canberra, ACT: National Centre for Development Studies.

Bell, J. (2006). Marijuana, guns, crocodiles and submarines: Economies of desire in the Purari Delta. Oceania, 76(3), 220-234.

Blades, J. (2020, 24 April). Pandemic exposes weakness of PNG's border security. Radio New Zealand. Retrieved from rnz.co.nz/international/pacificnews/415003/pandemic-exposes-weakness-of-png-s-border-security

Bourke, R. M., Allen, B. \& Lowe, M. (2016). Estimated impact of drought and frost on food supply in rural PNG in 2015 [Policy brief 11]. Retrieved from devpolicy.org/publications/policy_briefs/PB11PNGdrought.pdf

Business Advantage Papua New Guinea. (2012a). Tabubil: A college town in the clouds. Retrieved from businessadvantagepng.com/tabubil-a-college-town-inthe-clouds/

Business Advantage Papua New Guinea. (2012b). Beyond mining: Interview with Ok Tedis Nigel Parker. Retrieved from businessadvantagepng.com/beyondmining/

Business Advantage Papua New Guinea. (2012c). Ok Tedis Nigel Parker on social responsibility in mining. Retrieved from businessadvantagepng.com/ok-tedisnigel-parker-on-social-responsibility-in-mining/

Business Advantage Papua New Guinea. (2015). Restructure will see 25\% reduction of Ok Tedi staff and switch to 'fly in-fly out' operation at Papua New Guinea mine. Retrieved from businessadvantagepng.com/restructure-will-see-25-reductionof-ok-tedi-staff-and-switch-to-fly-in-fly-out-operation-at-papua-new-guineaminel

Business and Human Rights Resource Centre. (2018). Ok Tedi Mining's company response. Retrieved from business-humanrights.org/en/papua-new-guinea-oktedi-mining-terminates-191-employees-following-protest-to-request-betterwork-conditions-benefits 
Carr, P. \& Filer, C. (2011). Plans to close the Ok Tedi Mine in Papua New Guinea. Exploitation et Gouvernance Minière dans le Pacifique, 1-5. Noumea, New Caledonia: Institut de Recherche pour le Développement. Retrieved from nouvelle-caledonie.ird.fr/content/download/41887/318828/version/1/ file/carr+filer.pdf

Cox, J. \& Phillips, G. (2015). Sorcery, Christianity and the decline of medical services. In M. Forsyth \& R. Eves (Eds), Talking it through: Responses to witchcraft and sorcery beliefs and practices in Melanesia (pp. 37-54). Canberra, ACT: ANU Press. doi.org/10.22459/TIT.05.2015.02

Craig, B. (1990). The Telefomin murders: Whose myth? In B. Craig \& D. Hyndman (Eds), The children of Afek: Tradition and change among the Mountain Ok of Central New Guinea (pp. 115-150). Sydney, NSW: Oceania Publications.

Elapa, J. (2015a, 4 August). Financial crisis hit Kiunga, Tabubil as Ok Tedi mine scales down. Papua New Guinea Post-Courier.

Elapa, J. (2015b, 10 August). OTML to open in early 2016. Papua New Guinea Post-Courier.

Elapa, J. (2019, 2 September). Road brings hope for Bolangun. The National. Retrieved from thenational.com.pg/road-brings-hope-for-bolangun/

EMTV. (2018, 12 August). OTML signs agreement with OTM Allied Workers Union. EMTV Online. Retrieved from youtube.com/watch?v=61qJlIb8w SU\&t $=4 \mathrm{~s}$

Englund, H. \& Leach, J. (2000). Ethnography and the meta-narratives of modernity. Current Anthropology, 41(2), 225-248.

Esila, P. (2020, 15 April). Mine unaffected so far. The National. Retrieved from thenational.com.pg/mine-unaffected-so-far/

Ferguson, J. (1999). Expectations of modernity: Myth and meanings of urban life on the Zambian Copperbelt. Berkeley, CA: University of California Press.

Filer, C. (1990). The Bougainville Rebellion, the mining industry and the process of social disintegration in Papua New Guinea. Canberra Anthropology, 13(1), 1-39. doi.org/10.1080/03149099009508487

Filer, C. \& Jenkins, P. (2017). Negotiating community support for closure or continuation of the Ok Tedi Mine in Papua New Guinea. In C. Filer \& P. Y. Le Meur (Eds), Large-scale mines and local-level politics: Between New Caledonia and Papua New Guinea (pp. 229-259). Canberra, ACT: ANU Press. doi.org/ 10.22459/LMLP.10.2017.08 
Forsyth, M. \& Eve, R. (Eds). (2015). Talking it through: Responses to sorcery and witchcraft beliefs and practices in Melanesia. Canberra, ACT: ANU Press. doi.org/10.22459/TIT.05.2015

Forsyth, M., Putt, J., Bouhours, T. \& Bouhours, B. (2017). Sorcery accusationrelated violence in Papua New Guinea: Part 4: Trends over time and geographic spread (Department of Pacific Affairs, In Brief, 31). Canberra, ACT: The Australian National University.

Garrett, J. (2013, 6 January). PNG's Ok Tedi: From disaster to dividends. Australian Broadcasting Corporation. Retrieved from abc.net.au/news/201301-07/an-radio-doco3a-ok-tedi/4455092

Garrett, J. (2015, 8 December). Ok Tedi to shed more than 100 workers in PNG. ABC News Pacific Beat. Retrieved from abcmedia.akamaized.net/news/ pacificbeat/audio/201512/PABm_OkTediCuts_0812_nola.mp3

Gerega, L. (2019, 24 June). Marape tells Awi Yoto to improve Western. Papua New Guinea Post-Courier. Retrieved from postcourier.com.pg/marape-tellsawi-yoto-improve-western/

Gerritsen, R. \& Macintyre, M. (1991). Dilemmas of distribution: The Misima gold mine, Papua New Guinea. In J. Connell \& R. Howitt (Eds), Mining and indigenous peoples in Australasia (pp. 35-53). Sydney, NSW: Sydney University Press.

Gibbs, P. (2012). Engendered violence and witch-killing in Simbu. In M. Jolly, C. Stewart \& C. Brewer (Eds), Engendering violence in Papua New Guinea (pp. 107-136). Canberra, ACT: ANU E Press. doi.org/10.22459/ EVPNG.07.2012.03

Gibbs, P. (2015). Practical church interventions on sorcery and witchcraft violence in the Papua New Guinea Highlands. In M. Forsyth \& R. Eves (Eds), Talking it through: Responses to sorcery and witchcraft beliefs and practices in Melanesia (pp. 309-327). Canberra, ACT: ANU Press. doi.org/10.22459/ TIT.05.2015.17

Gunga, T. (2015, 29 July). Mirisim: OTML employees and contractors layoff is an injustice. EMTV News. Retrieved from emtv.com.pg/mirisim-otml-employeeslayoff-is-an-injustice/

Gware, C. (2018, 12 August). OTML industrial agreement signed. Loop PNG. Retrieved from www.looppng.com/business/otml-industrial-agreementsigned-78857 
Haley, N. (2008). Sung adornment: Changing masculinities at Lake Kopiago, Papua New Guinea. The Australian Journal of Anthropology, 19(2), 213-29. doi.org/10.1111/j.1835-9310.2008.tb00123.x

Haley, N. (2010). Witchcraft, torture and HIV. In V. Luker \& S. Dinnen (Eds), Civic insecurity: Law, order and HIVIAIDS in PNG (pp 219-35). Canberra, ACT: ANU E Press. doi.org/10.22459/CI.12.2010.11

Haslam, N. R. (2015). Post-mortem as preventative medicine in Papua New Guinea: A case in point. Rural and Remote Health, 15(4), 2861.

Howes, S. (2013a). PNG Sustainable Development Program to exit Ok Tedi. DEVPOLICYBLOG. Retrieved from devpolicy.org/sdp-to-exit-ok-tedi-2013 0604-2/

Howes, S. (2013b). The remarkable story of the nationalization of PNG's largest mine and its second largest development partner, all in one day. DEVPOLICYBLOG. Retrieved from devpolicy.org/ok-tedi-sdp-20130924/

Howes, S. \& Kwa, E. (2011). Papua New Guinea Sustainable Development Program review. Retrieved from www.pngsdp.org/independant-reviews/

Indeed.com (2019). Ok Tedi Mining Limited employee reviews. Retrieved from ca.indeed.com/cmp/Ok-Tedi-Mining-Limited/reviews?fcountry=ALL

Jacka, J. K. (2001). On the outside looking in: Attitudes and responses of nonlandowners towards mining at Porgera. In B. Imbun \& P. McGavin (Eds), Mining in Papua New Guinea: Analysis and policy implications (pp. 45-62). Waigani, Papua New Guinea: University of Papua New Guinea Press.

Jacka, J. K. (2015). Alchemy in the rainforest: Politics, ecology and resilience in a New Guinea mining area. Durham, NC: Duke University Press.

Jacka, J. K. (2019). Resource conflicts and the anthropology of the dark and the good in highlands Papua New Guinea. Australian Journal of Anthropology, 30(1), 35-52. doi.org/10.1111/taja.12302

Jackson, R. (1988). LDC: Has long-distance commuting a future in Papua New Guinea? Impact Assessment, 6(2), 109-125. doi.org/10.1080/07349165.1988. 9725639

Jackson, R. (1993). Cracked pot, or copper bottomed investment? The development of the Ok Tedi project 1982-1991, a personal view. Townsville, Qld: Melanesian Studies Centre, James Cook University.

Jackson, R., Emerson, C. A. \& Welsch, R. (1980). The impact of the Ok Tedi project. Boroko, Papua New Guinea: Department of Minerals and Energy. 
James, D. (2017, 14 February). Ok Tedi likely to have extended mine life, says CEO. Business Advantage PNG. Retrieved from businessadvantagepng.com/ ok-tedi-likely-to-have-extended-mine-life-says-ceo-peter-graham/

James, D. (2018, 12 June). Ok Tedi has moved from 'death row' to a 'sweet spot', says CEO. Business Advantage PNG. Retrieved from businessadvantagepng. com/ok-tedi-has-moved-from-death-row-to-a-sweet-spot-says-ceo/

Jenkins, P. (2016a). The politics of mine closure and sustainable development at the Ok Tedi Mine, Papua New Guinea (Doctoral thesis). The Australian National University, Canberra, ACT. doi.org/10.25911/5d7637756a8c5

Jenkins, P. (2016b). Sustaining community through the FIFO transition at Ok Tedi mine-Development, maintenance and staged closure in the North Fly. Paper presented at the Development Policy Centre conference 'PNG Update: Sustaining Development Beyond the Resource Boom'. Retrieved from devpolicy.org/Events/2016/PNG-Update/4a_Jenkins.pdf

Jorgensen, D. (1980). What's in a name: The meaning of meaninglessness in Telefolmin. Ethos, 8(4), 349-366. doi.org/10.1525/eth.1980.8.4.02a00060

Jorgensen, D. (1981a). Taro and arrows: Order, entropy and religion among the Telefolmin (Doctoral thesis). University of British Columbia, Vancouver, Canada. Retrieved from open.library.ubc.ca/cIRcle/collections/ubctheses/ $831 /$ items/1.0095526

Jorgensen, D. (1981b). Life on the fringe: History and society in Telefolmin. In R. Gordon (Ed.), The plight of peripheral people in Papua New Guinea (pp. 59-79). Cambridge, MA: Cultural Survival.

Jorgensen, D. (1983). Some notes on the geography of the Afek myth cycle from a Telefolmin point of view (Appendix 7.6). In P. Swadling (Ed.), How long have people been in the Ok Tedi impact region? Boroko, Papua New Guinea: PNG National Museum.

Jorgensen, D. (1990a). Telefolip, Telefolmin: The architecture of ethnic identity in the Sepik headwaters. In D. Hyndman \& B. Craig (Eds), The children of Afek: Tradition and change among the Mountain Ok of Central New Guinea (pp. 151-160). Sydney, NSW: Oceania Monographs.

Jorgensen, D. (1990b). Placing the past and moving the present: Myth and contemporary history in Telefolmin. Culture, 10(2), 47-56.

Jorgensen, D. (1993). Money and marriage in Telefolmin. In R. Marksbury (Ed.), The business of marriage: Transformations in Oceanic matrimony (pp. 57-82). Pittsburgh, PA: Pittsburgh University Press. 
Jorgensen, D. (1996). Regional history and ethnic identity in the Hub of New Guinea: The emergence of the Min. Oceania, 66(3), 189-210. doi.org/ 10.1002/j.1834-4461.1996.tb02551.x

Jorgensen, D. (1997). Who and what is a landowner? Mythology and marking the ground in a Papua New Guinea mining project. Anthropological Forum, 7(4), 599-627. doi.org/10.1080/00664677.1997.9967476

Jorgensen, D. (2006). Hinterland history: The Ok Tedi mine and its cultural consequences in Telefolmin. The Contemporary Pacific, 18(2), 233-263. doi.org/10.1353/cp.2006.0021

Jorgensen, D. (2014). Preying on those close to home: Witchcraft violence in a Papua New Guinea village. The Australian Journal of Anthropology, 25(3), 267-286. doi.org/10.1111/taja.12105

Jorgensen, D. (2016). The garden and beyond: The dry season, the Ok Tedi shutdown and the footprint of the 2015 El Niño drought. Oceania, 86(1), 25-39.

Jorgensen, D. (2019). Afterword: Dark anthropology in Papua New Guinea? The Australian Journal of Anthropology, 30(10), 104-116.

Kemp, D. \& Owen, J. R. (2018). The industrial ethic, corporate refusal and the demise of the social function in mining. Sustainable Development, 26(5), 491-500.

Kenneth, G. (2019, 24 June). Govt to review FIFO_minister. Papua New Guinea Post-Courier. Retrieved from postcourier.com.pg/govt-review-fifo-minister/

Kepmewato, R. (2019, 3 July). Fly-in, fly-out tactic only leaves us shortchanged [Letter to the editor]. The National. Retrieved from thenational.com.pg/flyin-fly-out-tactic-only-leaves-us-shortchanged/

Kirsch, S. (2006). Reverse anthropology. Stanford, CA: Stanford University Press.

Knauft, B. (2019). Finding the good: Reactive modernity among the Gebusi, in the Pacific and elsewhere. The Australian Journal of Anthropology, 30(1), 84-103. doi.org/10.1111/taja.12303

Leach, J. \& Leach, E. (Eds). (1983). The kula: New perspectives on Massim exchange. Cambridge, England: Cambridge University Press.

Loop Business. (2019). Tabubil-Kiunga highway to be sealed. Retrieved from www.looppng.com/business/tabubil-kiunga-highway-be-sealed-85877

Loop Business. (2020a). OTML sets-up COVID-19 screening station. Retrieved from www.looppng.com/coronavirus/otml-sets-covid-19-screening-station-91416 
Loop Business. (2020b). Ok Tedi Mine continues to operate. Retrieved from www.looppng.com/business/ok-tedi-mine-continues-operate- 91558

Lyons, K. (2020, 23 March). Papua New Guinea declares state of emergency after first coronavirus case. The Guardian. Retrieved from theguardian.com/ world $/ 2020 / \mathrm{mar} / 23 /$ papua-new-guinea-declares-state-of-emergency-afterfirst-coronavirus-case

Macintyre, M. (1983a). The kula: A bibliography. Cambridge, England: Cambridge University Press.

Macintyre, M. (1983b). Warfare and the changing context of 'Kune' on Tubetube. JournalofPacific History, 18(1), 11-34.doi.org/10.1080/00223348308572456

Macintyre, M. (1994). Anthropology's histories: Dealing with time and transformation in the Pacific. Reviews in Anthropology, 22(4), 275-283. doi.org/10.1080/00988157.1994.9978071

Macintyre, M. (2008). Police and thieves, gunmen and drunks: Problems with men and problems with society in Papua New Guinea. The Australian Journal of Anthropology, 19(2), 179-193. doi.org/10.1111/j.1835-9310.2008.tb00121.x

Malkki, L. (1997). News and culture: Transitory phenomena and the fieldwork tradition. In A. Gupta \& J. Ferguson (Eds), Anthropological locations: Boundaries and grounds of a field science (pp. 86-101). Berkeley, CA: University of California Press.

Mann, A. (2015, 30 July). Writing was on the wall for Ok Tedi mine [Letter to the editor]. The National. Retrieved from thenational.com.pg/writing-wason-wall-for-ok-tedi-mine/

Mauludu, S. (2018a, 22 February). Mine group sacked. The National. Retrieved from thenational.com.pg/mine-group-sacked/

Mauludu, S. (2018b, 23 February). OTML confirms sacking. The National. Retrieved from thenational.com.pg/otml-confirms-sacking/

McGavin, P. A., Jones, L. T. \& Imbun, B. Y. (2001). In country fly-in/fly-out and national HR development: Evidence from PNG. In B. Y. Imbun \& P. A. McGavin (Eds), Mining in Papua New Guinea: Analysis and policy implications (pp. 113-132). Waigani, Papua New Guinea: University of Papua New Guinea Press.

McLeod, S. (2019). A billion reasons: The future of PNG's Sustainable Development Program. The Lowy Institute Interpreter. Retrieved from www.lowyinstitute.org/ the-interpreter/billion-reasons-future-png-sustainable-development-fund 
Middleton, A. (2014). Rostering overhaul extends Ok Tedi mine life. Retrieved from miningnews.net/leadership/news/1194966/rostering-overhaul-extendsok-tedi-life

Moore, S. F. (1987). Explaining the present: Theoretical dilemmas in processual ethnography. American Ethnologist, 14(4), 727-736. doi.org/10.1525/ ae.1987.14.4.02a00080

Moore, S. F. (1994). The ethnography of the present and the analysis of process. In R. Borofsky (Ed.), Assessing cultural anthropology (pp. 362-376). New York, NY: McGraw-Hill.

Morauta, M. (2014, 15 September). PNGSDP not drawing down on Long Term Fund [Press statement]. PNGBlogs. Retrieved from www.pngblogs. com/2014/09/pngsdp-not-drawing-down-on-long-term.html

Mou, F. (2018, 26 February). MP calls for probe in OTML staff sacking. Papua New Guinea Mine Watch. Retrieved from ramumine.wordpress. com/2018/02/26/mp-calls-for-probe-in-otml-staff-sacking/

Nalu, M. (2012, 5 September). Tabubil: after mine closure. The National. Retrieved from www.thenational.com.pg/tabubil---after-mine-closure/

Nanau, E. (2020, 30 April). More funding needed to safeguard borders. Papua New Guinea Post-Courier. Retrieved from postcourier.com.pg/more-fundingneeded-to-safeguard-borders/

Nash, J. \& Ogan, E. (1990). The red and the black: Bougainvillean perceptions of other Papua New Guineans. Pacific Studies, 13(2), 1-17.

National Statistical Office. (2009). Western Province socio-economic urban survey report 2009. Port Moresby, Papua New Guinea: National Statistical Office.

National Statistical Office. (2014). 2011 national population and housing census ward population profile: Southern Region. Waigani, Papua New Guinea: National Statistical Office.

Ok Tedi Mining Limited. (2012). Annual review: Our journey continues. Port Moresby, Papua New Guinea: Ok Tedi Mining Ltd. Retrieved from oktedi. com/who-we-are/annual-performance/annual-performance-2012/

Ok Tedi Mining Limited. (2013). Annual Review: A new dawn securing our future. Port Moresby, Papua New Guinea: Ok Tedi Mining Limited. Retrieved from oktedi.com/who-we-are/annual-performance/annual-performance-2013/ 
Ok Tedi Mining Limited. (2014). Annual Review. Port Moresby, Papua New Guinea: Ok Tedi Mining Limited. Retrieved from oktedi.com/who-we-are/ annual-performance/annual-performance-2014/

Ok Tedi Mining Limited. (2015a). Toksave: Resetting the business and dry weather action. Tabubil, Papua New Guinea: Ok Tedi Mining Limited.

OkTediMiningLimited.(2015b).Importantupdateandinformationforemployees. Electronic document available at: www.oktedi.com/attachments/article/227/ TOKSAVEImportantUpdateandInformationForEmployeesOnStandDown. pdf (accessed 12 December 2015).

Ok Tedi Mining Limited. (2015c, 3 December). Toksave: Coming back to OTML: What's different? Online bulletin. Electronic document available at: www.oktedi.com/media-items/news-releases/228-toksave-coming-back-tootml-what-s-different (accessed 12 December 2015).

Ok Tedi Mining Limited. (2016). Annual Review 2016. Port Moresby, Papua New Guinea: Ok Tedi Mining Limited. Retrieved from oktedi.com/who-weare/annual-performance/annual-performance-2016/

Ok Tedi Mining Limited. (2017). Annual Review 2017. Port Moresby, Papua New Guinea: Ok Tedi Mining Limited. Retrieved from oktedi.com/who-weare/annual-performance/annual-performance-2017/

Ok Tedi Mining Limited. (2018). Annual Review 2018. Port Moresby, Papua New Guinea: Ok Tedi Mining Limited. Retrieved from oktedi.com/who-weare/annual-performance/

Oxford Business Group. (2014). Nigel Parker, managing director \& CEO, Ok Tedi Mining, on the roles of townships and fly-in-fly-out employees in Papua New Guinea. Retrieved from oxfordbusinessgroup.com/viewpoint/buildinglasting-legacy-nigel-parker-managing-director-ceo-ok-tedi-mining-rolestownships-and-fly

Papua New Guinea Post-Courier. (2020a, 16 March). Two staff at Ok Tedi mine quarantined. Papua New Guinea Post-Courier. Retrieved from postcourier. com.pg/two-staff-at-ok-tedi-mine-quarantined/

Papua New Guinea Post-Courier. (2020b, 2 April). Take back PNG by banning fly-in fly-out. Papua New Guinea Post-Courier. Retrieved from webcache. googleusercontent.com/search?q=cache: $4 \mathrm{xLtmRJKHCEJ:postcourier.com.}$ pg/yu-tok-2-2/

Papua New Guinea Resources. (2016, 2 April). Ok Tedi implements fly in - fly out rosters. Papua New Guinea Resources. Retrieved from pngresourcesonline. com/ok-tedi-implements-fly-in-fly-out-rosters/ 
Papua New Guinea Sustainable Development Program (PNGSDP). (2011). Annual Report, 2011. Electronic document available at: www.pngsdp.org/ annual-reports/

Papua New Guinea Sustainable Development Program (PNGSDP). (2019). PNG Sustainable Development Program Ltd. Retrieved from pngsdp.org

Patjole, C. (2020, 24 April). Porgera mine extension application refused. Loop $P N G$. Retrieved from www.looppng.com/business/porgera-mine-extensionapplication-refused-91723

Peter, J. (2015, 3 August). OTML hiding truth about mine closure. The National. Retrieved from thenational.com.pg/otml-hiding-truth-about-mine-closure/

Pinen, J. (2015). Is it a social responsibility of the company to provide services such as schools? Comment on discussion of Fly-in, Fly-out policy at Ok Tedi in Abip Family Facebook group. Retrieved from www.evernote.com/shard/ s2/sh/14952083-f96d-4b65-b927-763ab644f544/69cd821136e54c9ad6ce6 d9ac82b41f3

Pintz, W. (1984). Ok Tedi: Evolution of a third world mining project. London, England: Mining Journal Books.

Poriambep, C. (2018, 27 February). Minister will not intervene in Ok Tedi mine sacking. Papua New Guinea Mine Watch. Retrieved from ramumine. wordpress.com/2018/02/27/minister-will-not-intervene-in-ok-tedi-minesacking/

Radio New Zealand. (2020a, 3 April). PNG governor wants 'shoot to kill' order at border. Retrieved from rnz.co.nz/international/pacific-news/413325/pnggovernor-wants-shoot-to-kill-order-at-border

Radio New Zealand. (2020b, 9 April). Emergency controls tighten on PNG borders. Retrieved from rnz.co.nz/international/pacific-news/413883/ emergency-controls-tighten-on-png-borders

Radio New Zealand. (2020c, 30 April). Tight control of movement in PNG's Kiunga, Tabubil. Retrieved from rnz.co.nz/international/pacificnews/415506/tight-control-of-movement-in-png-s-kiunga-tabubil

Saxer, M. \& Andersson, R. (2019). The return of remoteness: Insecurity, isolation and connectivity in the new world disorder. Social Anthropology, 27(2), 140155. doi.org/10.1111/1469-8676.12652

Shiftwork Solutions. (2014). Rostering for a sustainable future: A case study by Shiftwork Solutions. Retrieved from shiftworksolutions.com/assets/Uploads/ CaseStudy-OkTedi-Final.pdf 
The National. (2013, 25 June). Fly-in, fly-out concerns backed. The National. Retrieved from thenational.com.pg/fly-in-fly-out-concerns-backed/

The National. (2014, 19 February). Fly-in, fly-out slammed. The National. Retrieved from thenational.com.pg/fly-in-fly-out-slammed/

The National. (2018a, 31 July). Morobe opposes fly-in fly-out for Wafi-Golpu mine workers. The National. Retrieved from thenational.com.pg/morobeopposes-fly-in-fly-out-for-wafi-golpu-mine-workers/

The National. (2018b, 27 November). Fly-in fly-out system praised. The National. Retrieved from thenational.com.pg/fly-in-fly-out-system-praised/

Vari, M. (2019, 23 January). MP Mirisim supports no fly-in fly-out. Papua New Guinea Mine Watch. Retrieved from ramumine.wordpress.com/2019/01/24/ mp-mirisim-supports-no-fly-in-fly-out-for-frieda-mine/

Wilkins, A. (2013, 9 December). 'Just like riding a tiger': Ok Tedi's CEO reflects on a momentous year. Business Advantage Papua New Guinea. Retrieved from businessadvantagepng.com/just-like-riding-tiger-ok-tedi-minings-ceoreflects-momentous-year/ 
This text is taken from Unequal Lives: Gender, Race and Class in the Western Pacific, edited by Nicholas A. Bainton, Debra McDougall, Kalissa Alexeyeff and John Cox, published 2021 by ANU Press, The Australian National University, Canberra, Australia.

doi.org/10.22459/UE.2020.10 